\title{
QUERELA DOS UNIVERSAIS, DIREITO E PERSONALIDADE
}

\section{Walter Lucas Ikeda ${ }^{1}$ Alessandro Severino Vallér Zenni ${ }^{2}$}

Resumo: O objetivo inicial foi de investigar o nominalismo e todo o contexto que o circunda. A metodologia utilizada foi a hipotético-dedutivo, com pesquisas em artigos, dissertações, teses e livros. Os resultados indicam que o debate dos universais ainda não terminou e este reverbera no direito e na personalidade.

Palavras-chaves: Querela dos universais. Idade média. Realismo e nominalismo. Direito e personalidade.

\section{INTRODUÇÃO}

O objetivo inicial da pesquisa foi de aprofundar tema do nominalismo e as suas circunstâncias e contextos. Ocorre que ao longo da pesquisa, foi detectado que o tema abrangeria uma dimensão histórica muito maior, de modo que recortar essa abrangência prejudicaria a riqueza e sentido do debate que só pode ser percebido ao leigo de forma mais contextualizada. A extensão do tema na pesquisa justifica uma relativa larga bibliografia e deveras diversificadas, visto que foi tratado quase dois milênios e meio do debate. A escolha do tema foi de se perceber a importância do nominalismo na modernidade, muitas vezes indicando a figura de Guilherme de Ockham.

A metodologia utilizada foi a hipotético-dedutiva, feita exclusivamente com documentos científicos tais quais dissertações de mestrado, teses de doutorado, artigos de revistas e livros, estes dois últimos, tanto de fontes nacionais como estrangeiras. A larga bibliografia também se justifica de não termos muitos trabalhos específicos ao tema, mas que costumam fazer menções, por vezes breves ao assunto.

A hipótese inicial é a de que o nominalismo surgiria com Guilherme de Ockham ao lado de uma doutrina de direitos subjetivos que trariam o individualismo da modernidade.

\footnotetext{
${ }^{1}$ Mestrando em Ciências Jurídicas na Cesumar. Pós-graduado pela PUCPR. Graduado em Direito pela Faculdade de Direito de São Bernardo do Campo. Unicesumar. Brasil. E-mail: walterlucasikeda@gmail.com.

${ }^{2}$ Mestre em Direito Negocial pela Universidade Estadual de Londrina e doutor em Filosofia do Direito pela Pontifícia Universidade Católica de São Paulo. Pós-Doutor na Universidade de Lisboa. Atualmente é professor concursado titular em Direito e Processo do Trabalho na Universidade Estadual de Maringá, Professor da Faculdade de Ciências Sociais Aplicadas de Cascavel Univel, professor titular - Faculdades Maringá. Doutor pela Pontifícia Universidade Católica de São Paulo (PUCSP). E-mail: asvzenni@hotmail.com.
} 
O primeiro capítulo buscará tratar das raízes do problema, i.e., expor a fonte, fundamentos e contexto que erigiram o problema. Tentativa de trazer a riqueza do debate desde a nascente do tema com alguma tonalidade de contexto. Neste capítulo será visto principalmente os argumentos de Platão e de Aristóteles.

O segundo capítulo versará sobre a alta idade média, demonstrando como o debate iniciado na antiguidade foi levado à idade média e quais influências recebeu. Em especial, interessante analisar o papel de Porfírio e Boécio.

O terceiro capítulo tratará do embate na baixa idade média, contexto que trará centripetamente e mais incisivamente a razão de encontro com a religião. Destaca-se nesse período Roselino de compaignè e Guilherme de Ockham.

O quarto capítulo tratará da modernidade e de como o debate ainda teria de ser enfrentado pelas ideias que fundaram a modernidade. Foi dada uma atenção especial a Kant que legitimou o conhecimento científico da época e permite uma ligação com o direito.

O quinto capítulo trata da "recepção" que o direito teve das mudanças que a modernidade trouxe às estruturas sociais do ocidente. Da sua legitimidade e sua vinculação com a sanção com o modelo positivista. No início do capítulo tratou-se mais de Kant como moldura ao direito na modernidade, e ao final do capítulo, expôs-se, brevemente, algumas noções de Ronald Dworkin com suas críticas ao modelo positivista e sua tentativa de reaproximação da moral por meio dos princípios.

No sexto capítulo, o último, foi abordado as consequências do debate e da modernidade na personalidade. Desde uma concepção metafísica de personalidade, à modelos de identidade intermediários e o sujeito pós-moderno.

\section{QUADRO E RAIZ DO PROBLEMA.}

Quando o homem decidiu entender o mundo, consequentemente a si mesmo, surgiram diversas questões que até hoje continuam em aberto. Para saciarmos nossa sede, este desejo de saber que surge da admiração (MADUREIRA, 2014, p. 119), buscamos muitas vezes beber da fonte dos antigos, os gregos. Um ponto nerval para o entendimento do mundo é saber o que é a realidade e como posso tomar conhecimento dela, diga-se, podemos conhecer as coisas particulares que nos rodeiam por meio de ideias universais? Este conhecimento seria verdadeiro? (VILELA, 1986, p. 58).

A questão pode ser colocada a partir da discussão sobre como relacionamos nossa interpretação e a consequente explicação pela língua em relação aos objetos do mundo ao 
nosso redor. Há um problema ontológico intrínseco a isso, i.e., qual o estatuto ontológico dos universais (entes abstratos)? Ou ainda, é na verdade, uma questão da lógica? Mister contextualizar as raízes da pergunta e um trazer um breve aporte histórico de seu surgimento.

De 490 a 470 a.C., Esparta e Atena combateram e derrotaram os persas, a Grécia, assim, evitou se tornar uma colônia do império asiático. Nessa guerra, Esparta forneceu o exército e Atenas a marinha, esta marinha no pós-guerra se tornou frota mercante e Atenas ascendeu a uma das maiores cidades mercantes do mundo. A posição de Atenas como movimentado mercado e porto possibilitou o contato com muitas raças, culturas e cultos diferentes, o que frutificou comparações, reflexões e análises (DURANT, 1996, p. 30).

A realidade, em Atenas, era explicada a partir da magia, rituais e poderes sobrenaturais. A situação pós-guerra de Atenas mostrou que essas explicações eram diferentes em outras partes do globo, tornando os comerciantes cada vez mais céticos; e o desenvolvimento da ciência, matemática e astronomia voltadas ao comércio exigiam respostas diferentes para um povo que já não se saciava com as respostas daqueles que combateram os persas (DURANT, 1996, p. 30).

Os primeiros filósofos eram astrônomos que buscavam dar explicações para o que antes era atribuído aos mencionados rituais. A filosofia, assim, começou na acepção física que questionava o final e irredutível componente das coisas. Os famosos "sofistas" foram filósofos que começaram a observar o próprio pensamento e sua natureza. Mas foi com Sócrates que a pergunta sobre o homem teve profundidade de transformar a filosofia, questionando o que seria o homem e o que ele pode vir a se tornar (DURANT, 1996, p. 30$33)$.

Platão, discípulo de Sócrates, em seu livro VII, a partir do mito da caverna, passa a articular a realidade como dualidade entre mundo sensível e mundo das ideias, aqui há a percepção metafísica do ser, e de seu ideal universal, incólume ao devir e ao tempo (PLATÃO, 2008, p. 210 e ss), as ideias são projetadas como modelos independentes e autônomas diante do mundo sensível. ${ }^{3}$

Aristóteles (1985), discípulo de Platão, em Categorias, distingue type e token, ideia e conceito particular, respectivamente; de tal modo que não se limita a uma visão da linguagem, mas da própria realidade. Assim, no caso do token, trata de atributos particulares que não podem ser separados de uma individualidade, como a barba de Platão que não subsiste sem a

\footnotetext{
${ }^{3}$ Sobre críticas modernas à leitura metafísica de Platão, ver: CRESSONI, André. Idealismo e metafísica platônica - uma releitura a partir de Hegel. Revista de Estudos Filosóficos e Históricos da Antiguidade, Campinas, n. 29, jan-dez, 2015, p. 37-87. p. 44. Disponível em: https://www.ifch.unicamp.br/ojs/index.php/cpa/article/download/2227/1641. Acesso em: 01 de out. 2018.
} 
existência do próprio Platão, a significação impressa é do particular enquanto existência derivada dessa atribuição (RASCH, 2013, p. 34). Ainda, os universais seriam essências, substâncias que se encontram no interior das coisas e são obtidas pelo intelecto humano, em “categorias”, V (ARISTÓTELES, 1985).

Para fazer jus ao crédito intelectual, pode-se até mesmo denunciar que a discussão começou com Heráclito para quem o mundo é movimento, dinâmico e teria Parmênides como antítese, este defendeu que a realidade é estática e unitária, o que vemos em Heráclito seria um jogo de aparência. Platão viria tentar sintetizar seus antecessores, propôs uma realidade de duas dimensões, uma de Parmênides, com o seu famoso "mundo das ideias"; e o "mundo dos fenômenos" de Heráclito. O mesmo fez Aristóteles, acrescentou o elemento do devir para que o ente potencial (matéria, corresponde ao ente fenomênico) vá ao ato (forma, correspondente ao ente das ideias). O ser e não ser de Platão corresponderia, grosso modo, no "ser em ato" e "ser em potência" por meio do devir de Aristóteles (SOUZA, 2015, p. 23$32)$.

Outra influencia que não deve ser marginalizada é a de Sócrates, segundo Aristóteles, aquele ao se insurgindo aos sofistas, declarou que o verdadeiro objeto do conhecimento é aquilo que os seres individuais de um grupo determinado têm em comum. Algo universal, permanente e imutável em cada um desses particulares, e estes particulares teriam algo de efêmero e relativo (TORRES, 2007, p. 88).

Em breve síntese, por um lado, o pensamento platônico vê o universal como entidades separadas das coisas, como realidade em si, que formam os conceitos e percebem o ser individual. Por outro lado, o pensamento do estagirita vê o universal como concepção do intelecto, uma essência a ser extraída das coisas. Deveras, ambos concordam que podem conhecer o universal, pressuposto de compreensão da realidade, mas divergem sobre o estatuto ontológico do universal quanto a uma existência autônoma ou como produto da inteligência. ${ }^{4}$

Insisto com a tentativa de demonstrar o quadro do problema, a questão é também vista como o problema do gênero e espécie; os gêneros, como universais: são coisas, conceitos ou nomes? Quando penso em Platão e Aristóteles, ambos seriam homens, mas não são idênticos, tem suas particularidades, ambos são espécies do gênero homem. Este homem é o quê? Se ele existe, existe por si ou na nossa concepção intelectual?

\footnotetext{
${ }^{4}$ Para uma visão do nominalismo psicológico ver: JUNIOR, Pedro Leite. O nominalismo psicológico acerca dos universais em João Buridano. Revista Ágora, Espírito Santo, v.1, n.2, 2011, p. 225-242. Disponível em: <http://www.unicap.br/ojs/index.php/agora/article/viewFile/159/145>. Acesso em: 03 de out. 2018.
} 


\section{O PROBLEMA NA ALTA IDADE MÉDIA}

A alta idade média vai voltar à discussão sobre o estatuto ontológico dos universais, mas esta discussão vai ganhar contornos bem diferentes do iniciado na antiguidade. Um dos problemas começa com a ambiguidade de interpretações que puderam ser extraídas das obras de Aristóteles.

Pode ser observado em categorias II, "O homem individual existe na espécie homem e o gênero da espécie é animal" de forma a indicar que os homens individuais seriam exemplos da espécie humanidade, e "homem" por analogia, remeteria para o gênero animal indicando a filiação respectiva pela palavra "animal". Porém, a linguagem utilizada aponta a referência da espécie homem e um gênero animal, quando na verdade, afirma que homem e animal são substâncias secundárias (KNEALLE; KNEALLE, 1991, p. 200).

Esta e outras ambiguidades são trazidas por Porfírio de Tiro, um neoplatonista no século III d.C., que geram novos contornos ao debate que será designado pelos medievais como "querela dos universais". Por meio do texto Isagoge (268-270 d.C), fomentou-se reflexões que deram estofo para teses doravante intituladas "nominalismo" e "realismo" (Santos, 2003, p. 188). A obra interpreta as ideias de categorias aristotélicas e busca dialogar com as propostas de Platão, deslocando a quaestio ao campo do debate ontológico (CRUZ; SILVA, 2014, p. 50).

Ocorre que ao se encontrar perante as questões sobre a existência ou não dos universais, Porfírio (1994) não entra no mérito quanto à existência e natureza dos universais, entende estar além da lógica e do Órganon. Mas deixa tais questões em aberto, com três perguntas essenciais, a primeira "[...] no que se refere aos gêneros e as espécies, a questão de saber se elas são [1] realidades em si mesmas, ou apenas simples concepções do intelecto e, admitindo que sejam realidades substanciais"; a segunda "[2] se são corpóreas ou incorpóreas se, enfim," e a última "[3] são separadas ou se apenas subsistem nos sensíveis e segundo estes, é assunto que evitarei falar: é um problema muito complexo, que requer uma indagação em tudo diferente e mais extensa".

A obra de Porfírio assume importância que não deve ser menosprezada, os pensadores da época medieval vão adentrar ao tema tentando responder as perguntas deixadas pela obra, assim considerada a fundadora e norte da "querela dos universais". A escolástica neoplatônica tardia (Séc. V e VI) tratou da problemática dos universais, centralmente, a partir das Categorias de Aristóteles, em detrimento do problema trazido em Isagoge. Foi nesse contexto que Anicio Manlio Torcuato Severino Boécio (Ca. 480-524) teve grande mérito no debate. 
Boécio traduziu, interpretou e assimilou textos aristotélicos (exceto os Segundos Analíticos) e a Isagoge de Porfírio que foram objeto de diversos comentários. Ocorre que não se tratou de um tradutor neutro, e é lícito presumir que a tradição clássica ganhou significados originais. As traduções e comentários de Boécio são conhecidos como lógica vetus e foram até a metade do século XII (as fontes árabes da tradução dos segundos analíticos e da metafísica de Aristóteles somente circulam na idade média no fim do século XII e início do XIII) as únicas fontes da lógica antiga, com o predomínio da problemática apenas campo ontológico (SANTOS, 2003, p. 189).

Boécio argumenta contra o universo ontológico, ao mesmo tempo, uno e múltiplo. O faz por meio da via quantitativa ${ }^{5}$, de tal forma que entende ser impossível o universal ontológico, pois o universal não pode estar simultaneamente todo em muitos (BERTELLONI, 2012, p. 17).

Em relação às três questões de Porfírio, Boécio chega a algumas conclusões: de que tudo aquilo que é comum a muitas coisas, simultaneamente, não é hábil a ser uma coisa só, assim, o gênero não pode se encontrar em vários e ter uma unidade preservada. $\mathrm{O}$ universal não pode estar somente no intelecto, pois o intelecto vem antes do objeto, o objeto não pode ser abstraído (intelecto retira a substância do objeto) sem a intelecção primeira, de modo que deve existir algo na natureza das coisas, mas que não sejam substâncias próprias nem conceitos vazios do intelecto (SOUZA, 2015, p. 39-42).

$\mathrm{O}$ século $\mathrm{X}$ que marca passagem da alta idade média para a baixa idade média, tem após diversas invasões na Europa, certa consolidação de poder. Um dos povos que invadiram foi o dos Francos no século VII e VIII, consolidando um governo da dinastia carolíngia e dominaram grande parte da Europa ocidental. É no reinado de Carlos Magno (714-814) que surge um esmero de melhorar o nível intelectual e moral deu seu povo, apesar de históricapoliticamente ser coisa outra, houve uma retomada cultural romana preservada em grande parte pela igreja católica (GILSON, 1995, p. 213).

A igreja católica no final do século VI percebeu que apesar dos celtas terem sido parcialmente cristianizados, os anglo-saxões eram pagãos, e temendo uma futura invasão destes povos, enviou em 596, Agostinho com monges para a missão, que seriam "os primeiros passos da história da cultura intelectual da Europa Medieval" (GILSON, 1995, p. 214). A missão de Agostinho foi bem-sucedida, estrategicamente sabia-se que deveriam ter cleros indígenas, o que ocorrera num ritmo acelerado, em 644 teve um bispo inglês, seu sucessor

${ }^{5}$ Para uma análise detida sobre a via quantitativa: IMAGUIRE, Guido. O avestruz Nihilista. Revista Notae Philosophicae Scientiae Formalis, Santa Maria, RS, v.2, n.1, p.33-44, maio, 2013. Disponível em: $<$ http://gcfcf.com.br/pt/files/2013/07/Imaguire-Guido-NPSF-vol.-2-n.-1.pdf>. Acesso em: 12 de out. 2018. 
fora um anglo-saxão, e assim por diante. Mas um ponto que não deve ser deixado é que não se tratou de mera evangelização, mas que ocorrera concorrentemente com a importação da cultura latina (GILSON, 1995, p. 214).

Interessante destacar que Santo Agostinho, em A Cidade de Deus (sua obra-prima), escrita em decorrência das invasões, coloca a ordem natural absorvida pela sobrenatural, o que moldou um paradigma político ocidental do sagrado e do racional, que terá novas rupturas no século XVII com Rousseau (que negará o pecado original em Émile). Agostinho trata que a queda do império romano deve dar lugar ao tempo da redenção, a história como fenômeno cíclico entre o ser e o nada, um meio que chegará a um único fim, que é Cristo (CARVALHO, 2005, p. 51-55).

A estrutura traçada é a de que existem duas cidades, uma do amor de si e o desprezo de Deus - a terrena; outra do amor de Deus e o desprezo de si - a celeste. A dialética das oposições, uma de dominar, outra da caridade; este choque deve ser dirigido pelos chefes, os súditos devem obedecer, a fim de que o mundo sensível permita o gozo da paz terrestre na cidade terrena e o gozo da paz eterna na cidade celeste (CARVALHO, 2005, p. 52-53). Deste modo, apesar de não ser o escopo a ser explorado aqui com mais profundidade, a política ocidental tomou um pano de fundo teológico, mesmo na idade moderna (SCHMITT, 2009; ARAUJO, 2013; BRANCO, 2011).

No século VII, a Igreja julgava útil enviar sábios para a Inglaterra, o bispo Teodoro foi enviado, tratava-se de um monge grego, versado na língua sacra, profana, latina e grega; ao lado do abade Adriano, um africano, de nível cultural semelhante. Estes dois fomentaram, além do múnus que lhe foram incutidos, as ciências métricas, astronomia e cômputo eclesiásticos. Este é o berço da cultura clássica latina em solo inglês (GILSON, 1995, p. 214215).

O aporte feito nestes últimos parágrafos não serviu ao improfícuo, mas são eventos que influenciam diretamente o rumo da história ocidental, e o debate aqui traçado. Cem anos depois de acolherem os missionários romanos, a assimilação da cultura latina foi tão intensa, que se chegou o momento de os ingleses desejarem evangelizar outros. Winfrid foi um estudante brilhante que rapidamente ascendeu a mestre, e este foi o arauto escolhido para evangelizar o povo de origem, na Germânia, foi à Roma em 718 para ter o aval, obteve sucesso inquestionável na missão. O papa Gregório II (669-731), em 722, tornou-o primeiro bispo dos povos germânicos; em 742, Carlos Magno requestou sua ajuda para reorganizar a igreja na Áustria (GILSON, 1995, p. 216-218). 
Com a influência evangelizadora no futuro sacro império romano-germânico, Carlos Magno a partir da crença que deveria conduzir seu povo no caminho do senhor, como fez o rei Davi, só poderia ter recebido tal autoridade de Deus. Para que houvesse ordem, o primeiro dever dos súditos é estarem à serviço de Deus, para isso deveriam aprender a religião cristão, consequentemente, o ensino se tornou necessidade (GILSON, 1995, p. 223).

O desenvolvimento e disseminação do ensino, a reprodução de textos e livros começou a mudar a cultura europeia. Em especial, a gramática e a lógica chamavam atenção dos estudiosos, e a discussão metafísica passava a um segundo plano, até mesmo no interior da Igreja. As regras de dialética começam a contestar as escrituras sagradas, ressurgem sofistas e problemas filosóficos. São Pedro Damião (1007-1072) representa bem o quadro da questão no século XI, afastando a filosofia das escrituras, e que "o primeiro professor de gramática seria o demônio" (GN 3,5); enfrenta as objeções da ciência com grande eloquência (GILSON, 1995, p. 285-287). A base da argumentação de São Pedro Damião contém o germe do teologismo da onipotência de Deus que se expandirá na doutrina de Ockham (GILSON, 1995, p. 287).

\section{O PROBLEMA NA BAIXA IDADE MÉDIA}

A opinião que foi mais consentida até o século XII, com grande influência de Boécio, foi de que o universal deveria ter fundamentação na realidade, a própria realidade era tida como um universal. Contudo, não há seres universais na realidade, senão uma multiplicidade incontestável, carreando o problema da individuação, i.e., como o universal se individualiza para a existência dos seres individuais? (SOUZA, 2015, p. 13).

A celeuma continua até novas rupturas no século XII, em que as figuras de Guilherme de Champeaux (c. 1070-1121), Pedro Abelardo (1079-1142) e Roselino de Compiège (10501120) trazem novos contornos ao tema, oportunidade que nos leva a explorar sucintamente os pensamentos respectivos.

Guilherme de Champeaux trouxe a perspectiva do realismo exagerado que tem os universais como entes metafísicos perfeitos, validam sua existência em si mesma, autônomos em relação aos indivíduos concretos, as universalidades são semelhantes, mas não idênticas (TORRES, 2007, p. 93).

Mas é Roselino de Compiège que nos chama grande atenção, este parte de uma deontologia da linguagem, a cisão dos valores linguísticos da realidade, percebia os universais como meros nomes. Sem valor intrínseco ou particular, somente a individualidade é real, e o 
indivíduo só pode ser percebido na sua individualidade, de tal modo que esta vertente extremada na dimensão relativista sobrepõe o valor individual sobre o universal. Logo, se os universais são expressões de abstração que servem para designar indivíduos em particular, é mera emissão fonética, o universal à realidade física é flatus vocis. ${ }^{6} \mathrm{~A}$ linha de Roselino ficou conhecida como nominalismo. Nesta linha, a pergunta sobre o "homem" como universal, não significaria nada, a realidade é constituída apenas de particulares (GILSON, 1995, p. 289). Ainda, esta posição colocou Roselino de encontro com a Igreja católica, seus dogmas, em especial com a santíssima trindade. ${ }^{7}$

Pedro Abelardo, aluno tanto de Champeaux quanto de Compiège, trabalha um segmento designado realismo moderado. Busca-se um meio termo, uma terceira via para as teses, por meio de uma abordagem semântica ${ }^{8}$. A palavra universal tem um sentido significativo e outro referencial.

Por um lado, o sentido significativo fixa a intelecção na mente; por outro lado, a palavra indica algo além da aparência, a fim de conciliar ambos, extrai-se que a significação dos universais existe enquanto realidades contínuas evocadas por um nome comum ou por uma causa comum (TORRES, 2007, p. 94-95). Para este, ainda, os universais são termos com significados, e os significados como gênero são passíveis de chegar ao particular não porque é o mesmo elemento, mas semelhante (SANDOVAL, 2016) p. 63-64).

Pedro Abelardo, no século XII, criticará o nominalismo e o realismo exagerado, com base em pensamentos aristotélicos e eclesiásticos dogmáticos como a de que um cristão não deve colocar em dúvida o que é afirmado pela Igreja, deve agradecer ser apto a compreender ou aceitar e venerar (VASCONCELLOS, 2003, p. 10-11).

Uma observação é salutar neste, há que ser observado que o sagrado era a representação de um significante vazio. Este vazio seria preenchido com conteúdo

\footnotetext{
${ }^{6}$ Para uma visão que contesta esta interpretação, ver: RUSSELL, Bertrand. História da filosofia ocidental. São Paulo: Companhia editora nacional, 1969. Livro II.

Oportunamente, deve-se mencionar que de acordo com Gilson, haveria pensadores anteriores como Érico de Auxerre e o Pseudo Rabano que traziam ideias próximas. Cf. GILSON, Etienne. A filosofia na idade média, trad. Eduardo Brandão. São Paulo: Martins Fontes, 1995. p, 288.

${ }^{7} \mathrm{O}$ nominalismo à teologia, em especial à trindade, colocaria objeção ao entendimento que o pai, filho e espírito santo fossem um, mas que deveriam ser três pessoas distintas que compõem um uno que partilharia um poder e uma vontade (GILSON, Etienne. A filosofia na idade média, trad. Eduardo Brandão. São Paulo: Martins Fontes, 1995. p, 290). Para uma visão mais detida, ver: VASCONCELLOS, Manoel. A crítica de Anselmo a roselino na epistola de incarnatione verbi. Revistas Dissertatio, Pelotas, v.1, n.1718, 2003, p.5-27. p, 7.

${ }^{8}$ Para uma análise da Venerabilis Inceptor de Ockham e o externalismo da mente contemporânea, ver: FERREIRA, Anderson D'arc. Ockham e a filosofia da mente: aproximações ao externalismo na filosofia contemporânea. Revista Problemata - revista internacional de filosofia, v.2, n.1, 2011, p, 144-169. Disponível em: < http://www.periodicos.ufpb.br/ojs/index.php/problemata/article/view/10447>. Acesso em: 03 de out. 2018.
} 
significativo por meio de estratagemas de engajamento simbólico. Historicamente, a ideia de sagrado é inexorável à ideia de realidade, fonte de consciência e existência no mundo, não se trata apenas de crenças. A pertinência da observação é que se trata de um modo de compreender e explicar o início e fim de todas as coisas, a partir de uma percepção que transcende a realidade natural (BORGES, 2017, p. 32-33), assim como fora com os primeiros filósofos. Aliás, quando Cristo veio, causou grande perturbação daqueles que apenas tinham o conhecimento dos antigos, não entendiam a natureza de Cristo (este não seria nem particular nem universal, mas híbrido). ${ }^{9}$

Uma vez que os universais são despidos de valor de verdade, todo o acesso ao conhecimento se limita aos sentidos, que será hipóstase dos empiristas modernos. O nominalismo tem a característica positiva de conter respostas mais fundamentalmente lógicas - motivo pelo qual ele vai ser tão bem acolhido na modernidade.

Roselino não foi o primeiro a propor a abstração de valor ontológico na linguagem. Os sofistas já haviam deslocado a pesquisa filosófica do cosmos para o humano, e acreditavam na verdade como convenção, todo o conhecimento seria relativo; logo, a linguagem não teria relação com a realidade.

Os entraves sobre os universais e seu estatuto ontológico, "querela dos universais", terá nova ruptura como ponto central na filosofia de Guilherme de Ockham (1285-1347), Duns Scot (1266-1308) e Mestre Eckhart (1260-1327) que estarão contextualizados no embate entre poder religioso e poder secular do século XIV.

O século XIV foi marcado pelo crescimento da estrutura monárquica e a instabilidade gerada pelo excesso de poder, a princípio não havia embate por uma dualidade do poder em reino divino e universal ao lado do poder secular. Mas se podia perceber que a dualidade não seria longa. Na Inglaterra (Terra de Ockham), houve a legislação antipapal para disputas de jurisdição (AZEVEDO, 2010, p. 23).

A crise do poder papal acaba por surgir da própria divergência entre os valores pregados e sua prática, da vida cristã dos primeiros evangelistas daqueles do século XIV, muito mais próximos às elites romanas e judaicas que perseguiram os primeiros cristãos. $\mathrm{O}$ século XIII foi marcado por São Francisco revitalizando um modo de vida que não se compatibilizava com a prática papal, a Igreja buscou forçar os fiéis a aceitarem as crenças dos primeiros e ignoravam a tentativa de aproximar o novo perfil de fieis, cada vez mais a heresia se disseminava (AZEVEDO, 2010, p. 24-25). Com efeito, a ordem de São Francisco

\footnotetext{
9 Para uma análise sintética e tomista-aristotélica da natureza da santíssima trindade, ver: ZENNI, Alessandro Severino Váller. Pessoa e justiça: questão de direito. Porto Alegre: Sergio Antonio Fabris. 2018, p, 22-23.
} 
ia de encontro ao interesse do poder papal, buscavam a defesa máxima evangélica por meio de uma vida religiosa.

Johann Eckhart (Mestre Eckhart), filiado à ordem dominicana, grande neoplatonista, parte de uma concepção inversa de Tomás de Aquino, no sentido que Deus não conhece porque é, mas é porque conhece. Deus seria o máximo da universalidade, se a vista deve ser incolor para enxergar todas as cores, Deus não deve ter nenhum ser para ser causa de todo ser. Pai seria inteligência, o filho o viver, e o Espírito Santo esse, Deus é uno e "a imóvel unidade, o repouso, a solidão e o deserto da deidade" (GILSON, 1995, p. 864-867).

O Mestre, sucessor do neoplatonismo de Agostinho, Avicena e Alberto Magno, vê a alma como substância espiritual, e vai além de Agostinho sobre as faculdades da alma (memória, intelecto e vontade), fala da "citadela" ou centelha da alma. Uma centelha do intelecto divino, una e simples, este é incriável e incriado; tal preposição permitiu novas construções da moral e que o homem pertenceria ao Uno (GILSON, 1995, p. 869).

A fim contrastar os métodos atuais das ciências, o método de Eckhart para alcançar o conhecimento absoluto, propõe que o indivíduo intencionalmente abstraia sua própria representação mental de qualquer coisa, de forma a ter uma identidade formal com o objeto representado. Com inspiração doutrinária abstrativa de Aristóteles, coloca-se a mente num estado deserto, estado sem conhecimento algum, este é o conhecimento absoluto do objeto representado (AUGUSTO, 2008, p. 166).

John Duns Scot, franciscano, escocês, teve estudos em Paris e lá lecionou, além de ter estudado em Oxford. A estrutura de seu pensamento era que Deus era objeto da teologia, a metafísica e a filosofia estudam o ser enquanto ser. Assim, a filosofia só pode entender Deus enquanto ser, mas não Deus em si. O homem conhece do sensível, logo, só conhece do ser o que os sentidos captam; mas não há conceito direto para substâncias imateriais e inteligíveis em que situa o divino (GILSON, 1995, p. 736-737). A ideia de Eckhart está longe de ser simples, há uma dialética mística que envolve um homem de profundo amor a Deus, um sentimento intenso da presença divina e que requisitava a dialética como meio de comunicar aos homens toda essa profundidade, densidade de seus sentimentos.

Para evitar que a ciência se tornasse uma simples lógica, para evitar que não houvesse diferença entre metafísica (estuda o ser) e a lógica (estuda o conceito), Scot faz uma divisão. A essência conteria tanto o universal quanto o individual, mas com eles não se confundiria; o universal é produto do intelecto cujo fundamento está nas coisas, a indeterminação da essência permitira isso, de modo que nosso intelecto captaria nos indivíduos a essência e lhe atribuiria universalidade (GILSON, 1995, p. 746). 
A posição de Scot (também a de Aquino) tentou limitar o alcance da filosofia no século XIII, buscando uma convivência pacífica entre teologia e os demais conhecimentos, mas o século XIV apresentava-se uma crítica que se iniciava desafiando o próprio Scot. Ockham parte da ideia de limitação da filosofia de Scot e vai além, insurge-se ao realismo de Scot e cria um abismo entre filosofia e teologia (GILSON, 1995, p. 796-800).

Guilherme de Ockham pertencia à ordem franciscana, estudou em Oxford, devido aos problemas internos da ordem religiosa causados pelos problemas mencionados (como o excesso de poder e a ordem franciscana), Ockham, na carta aos frades menores, opõe-se ao então papa por meio de críticas aos escritos de João XXII, com apoio dos franciscanos, os argumentos centrais são azoados na pura razão e experiência. Chega a criticar a legitimidade do imperador pela coroação, que viria do povo ao decidir eleger um governante para si (CAMPELO, 2016, p. 25). ${ }^{10}$ A estratégia tem no plano de fundo a ideia de Aristóteles sobre a constituição da política e do bem comum, não será a religião nem a filosofia que poderão dizer o que é o bem comum, apenas a reta razão é capaz de discernir o que é o bem comum (CAMPELO, 2016, p. 25). ${ }^{11}$

O que caracteriza o nominalismo de Ockham é a visão ontológica que restringe a existências às entidades individuais (substância e qualidade), as entidades universais são afastadas (meros conceitos e palavras) (JUNIOR, 2011, p. 32). Não se trata de ser o primeiro a entender que universal não existe, ou que tentou provar, mas que assim compreendeu e provou (GILSON, 1995, p. 799) para sua época. Fora pregado a ideia do princípio da redução necessária, que deveríamos reduzir A para B quando possível, pois a interpretação "redução como irreal" mostra que A é mera ficção (IMAGUIRE, 2008, p. 144).

\footnotetext{
${ }^{10}$ Interessante apontar que a legitimidade não é apenas o reconhecimento internacional de um Estado, mas há outro sentido, este que interessa ao contexto apresentado, mas um mais importante que precede o anterior, a legitimidade é o reconhecimento da população que os que lhe governam são os verdadeiros titulares do poder e tem o direito de exercê-lo, criando e aplicando direitos dispondo para tanto, do monopólio da força (HERNÁNDEZ, José López. El concepto de legitimidad em perspectiva histórica. Revista cuadernos eletrónicos de filosofia Del derecho, - el institut de La universitat de valència, Espanha, n. $18, \quad$ v. $1, \quad 2009, \quad$ p. 153-166. p, $156 . \quad$ Disponível em:<https://ojs.uv.es/index.php/CEFD/article/view/116/124>. Acesso em: 06 de out. 2018.

${ }^{11}$ Oportunamente, Ockham, no campo jurídico, não trata do plexo de direitos como os naturais ou os positivos, a imago dei dá dignidade e liberdade que são levantadas por meio de um complexo de direitos subjetivos. Estes direitos subjetivos teriam sua alçada para além da negligencia da filosofia do direito para com tais, transcende o técnico-jurídico, chega ao plano da ética, moral e política. (GUERRA FILHO, Willis Santiago; e CANTARINI, Paola. Teoria poética do direito. Rio de janeiro: Lumen Juris, 2015). Para uma análise do problema e sua correlação com os direitos humanos, ver: GUERRA FILHO, Willis Santiago. Sobre a origem medieval de noções modernas como a de direitos humanos, Revista Panóptica, Vitória, $\begin{array}{lllllll}\text { v.8, n.2 } & \text { (n.26)m } & \text { p. 15-40, jul/dez. 2013. Disponível em: < }\end{array}$ http://www.panoptica.org/seer/index.php/op/article/view/308/329>. Acesso em: 05 de out. 2018.
} 
O papa João XXII hostiliza os franciscanos por meio da bula cum internon nullos, declarando heresia a partir da interpretação de que Jesus e seus apóstolos não tinham bens, nada possuíam e que não tinham direito de uso sobre os bens, nem compra nem venda, na forma do direito civil. Esta concepção papal atacava diretamente o modo de vida franciscano, dividiu a ordem naqueles que seguiriam Pedro e os rebelados que seguiriam São Francisco. Ockham foi um rebelado, contesta a tese papal por meio de uma regressão histórico-teológica até Adão e Eva, antes do pecado original não havia propriedade, mas distribuição comunitária do uso das coisas. Logo, a propriedade não é criação divina, mas humana com fundamento no direito e na vontade dos homens (MARQUES, 2015, p. 815-817).

Ockham abalou a estrutura social medieval e o pensamento escolástico, pensamento que veio a se tornar soberano na Europa. No plano jurídico instou os juristas a procurarem fundamentos no indivíduo, da vontade expressa e positivada, seja dos homens ou de Deus, não mais na natureza e de sua ordem. No futuro, estas ideias vão dar estofo para as teorias de Hobbes e Locke moldarem o positivismo jurídico (MARQUES, 2015, p. 819-820).

O nominalismo de Ockham dá base para criar uma nova definição de certeza científica (percebida como empirismo radical) que não reconhece válida para o indivíduo qualquer proposição que não imediatamente evidente ou passível de dedução de uma preposição imediatamente evidente para os sentidos. ${ }^{12}$ As ideias de Ockham vão levar o pensamento medieval para além da escolástica por meio da via moderna (NASSARO, 2005, p. 49). Assim nascerá o homem moderno cuja filosofia moderna ostenta razão hábil a afastar a autoridade de Aristóteles (ainda havia o uso das lições, mas com interpretações completamente diferentes dos seus antecessores) (GILSON, 1995, p. 816-818).

Erasmo de Rotterdam percebe que o que está em jogo é o debate da via antiqua e da moderna. A primeira é de via solidária, da bondade de Deus, herdeira do necessitarismo grego e do platonismo radical que veem o Deus Cristão como uma natureza boa ou como o bem. A via moderna separa a fé e a razão, suprime-se as essências e os universais, afasta tudo que é divino reverberando grandes rupturas morais, Deus deixa de ser natureza e passa a ser liberdade, não há vinculação alguma com as sagradas escrituras, senão arbítrio e o imprevisível (NASSARO, 2005, p. 49-50).

Erasmo, ainda, concorda com algumas lições de Ockham, em Contra vanam curiositatem in negotio fidei de 1402 e no seu De concórdia metaphysicae cum lógica de 1426, no sentido de que a tentativa de lógica para a metafísica e da metafísica para a lógica

\footnotetext{
${ }^{12}$ NASSARO, Silvio Lúcio Franco. A unidade da verdade em Erasmo. 2005. 183 f. Dissertação (Mestrado em filosofia) - universidade de São Paulo, SP. p, 49.
} 
no século XIV pouco traria frutos, a razão natural não pode conhecer Deus, e as essenciais não mais do que abstrações, logo metafísicas e em breve teologia. Aponta, outrossim, que o erro do realismo é crer que o universal do intelecto, a existência do universal separadamente e abstratamente, abstrata e separadamente nas coisas e em Deus. ${ }^{13}$

\section{MODERNIDADE}

A discussão aqui tratada terá influencia direta no pensamento moderno, apesar do preconceito com o pensamento medieval, o debate sobre o estatuto ontológico dos universais é a viga mestre, ainda que oculta, dos pensadores modernos.

No século XVII, a concepção prevalecente foi a do conceptualismo. Admite a existência dos universais, mas que não ostentam correspondência com a realidade. Distanciase um pouco do nominalismo radical que vê os universais apenas como palavras, e a realidade seria uma coleção de indivíduos (COXITO, 1994, p. 295).

A linha conceptualista influenciará tanto racionalistas quanto empiristas, v.g, Descartes (1596-1650), em “princípios da filosofia”, entende que o universal não existe na coisa, somente no espírito. O francês elegeu como primeiro princípio "não aceitar jamais alguma coisa como verdadeira que eu não conhecesse evidentemente como tal" (DESCARTES, 2005, p. 54), também no item 59 da sua obra "princípios de filosofia", expõe que "Os universais derivam apenas do facto de no servirmos de uma ideia para pensar várias coisas particulares que tem certa relação entre si", e que "quando num mesmo nome compreendemos as coisas representadas por tal ideia, esse nome é também universal" (DESCARTES, 2004, p. 48).

Locke tenta estabelecer uma doutrina dos universais, oferece o empirismo como explicação de conhecimento da realidade, partindo do pressuposto de que a realidade tem origem e fundamentação lógica apenas na experiência. Rejeita o realismo nos moldes anteriores e propõe um realismo diferente do aristotélico-escolástico (COXITO, 1994, p. 297 298). A ideia os universais de Locke acaba ficando muito obscura e confusa, de tal forma que não se sabe ao certo o que foi proposto (AARON, 1952, p. VII, apud, COXITO, 1994).

\footnotetext{
${ }^{13}$ Ainda, há que se fazer a defesa que Erasmo não era um ockhamista, havia um ceticismo em seus escritos, mas tinha esperança de uma verdade única acessível ao homem em algum grau. De forma que ainda se pode falar em um escritor cristão, impaciente com os dogmas religiosos, mas metafísico em sua natureza mais profunda (NASSARO, Silvio Lúcio Franco. A unidade da verdade em Erasmo. 2005. 183 f. Dissertação (Mestrado em filosofia) - universidade de São Paulo, SP. p, 52-53).
} 
Entrementes, há posições mais voltadas para o nominalismo radical como o de Hobbes (2009, p. 32-34) (1588-1679) para quem "A mente humana não conhece outras ações além das sensações [...]", assim só podemos conhecer algo que esteja em local determinado, com alguma magnitude e suscetível de divisão, "não é possível que algo esteja em dois lugares ao mesmo tempo; nem que duas coisas ocupem o mesmo lugar ao mesmo tempo", nada disso é filtrado pela percepção, não há significado algum, exarado por filósofos enganados e escolásticos enganadores ou enganados. Por derradeiro, arremata: "Nada no mundo é mais universal que os nomes, sendo cada uma das coisas denominadas individual ou singular".

Immanuel Kant (1724-1804) encabeçou uma corrente idealista ao tema. Os universais não seriam apenas sons vocais (nominalismo) nem teriam existência independente (realismo). Kant defenderá que os universais são categorias fundamentais da razão (noumena), ou conceitos secundários que derivam destes. O problema para Kant, assim, para os idealistas, é epistemológico. ${ }^{14} \mathrm{Em}$ verdade, na metafísica dos costumes, o conhecimento possível se restringiria ao que se apresenta a mim, aos sentidos, "ficando-nos assim desconhecido o que eles em si mesmos possam ser", pois não conseguimos, ainda que com grande esforço, conhecer as coisas em si, "senão somente ao conhecimento dos fenómenos, e nunca ao das coisas em si mesmas" (KANT, 2007, p. 99).

O filósofo de Königsberg trouxe consistência ao problema da tradição empirista que tinha na sensação a fonte de conhecimento, mas incongruências eram produzidas quando se deparava com a relação entre sentidos e cognição racional (SANTOS, 2007, p. 60-61). Dessa forma, a hipóstase de legitimidade do conhecimento das ciências modernas, tanto o empirismo britânico como o racionalismo continental, foram endossados de uma fundamentação na experiência, mas não neutra, pois há formas a priori da sensibilidade e do entendimento, próprios da cognição humana (SILVEIRA, 2002).

Destarte, todo fenômeno seria filtrado pela sensibilidade (espaço e tempo), gerando a percepção (juízo analítico); esta seria submetida à razão (conceitos e princípios no entendimento) (juízo a posteriori), deste juízo escalonado resultaria no conhecimento das coisas para nós (KANT, 2008).

\footnotetext{
${ }^{14}$ Contudo, há que se fazer uma ressalva, o idealismo faz uma oposição ao realismo no sentido que a realidade última na natureza é a ideia, ou seja, depende da concepção intelectual; mas acreditam na realidade das ideias, então há uma concepção realista de natureza diversa (HAMLIN, Cynthia Lins. Realismo crítico: um programa de pesquisa para as Ciências Sociais. Revista Dados - Instituto de Estudos Sociais e políticos (IESP) da unversidade do Estado do Rio de Janeiro, Rio de Janeiro, v. 43, n. 2, p. 00, 2000. Disponível em: <http://www.scielo.br/scielo.php?script=sci_arttext\&pid=S001152582000000200006\&lng=en\&nrm=iso $>$. Acesso em: 12 de out. 2018).
} 
Kant além de tratar da forma de conhecer e do que conhecer, traz uma antropologia do ser humano inclinado à violência, precisamente, para o mal. no seu Antrhropologie in pragmatischer hinsicht, trata que a vontade própria do indivíduo está sempre na iminência de voltar-se contra o próximo em busca da liberdade incondicionada, mas, além disso, para subjulgar aqueles de igual natureza. A pergunta do homem, para Kant, é vista como uma antropologia da violência (SARDINHA, 2008, p. 51-52).

As dimensões do homem (correlação do que faz; o que pode fazer; e o que deve fazer de si) que propõe Kant, também tem correlação com as três perguntas, na crítica da razão pura, que sintetizavam o interesse da razão (que posso saber? que devo fazer? quem me é permitido esperar?). Na mesma obra, é trabalhado o particular e o universal, como do $e u$ vai ao homem, em que surge uma quarta pergunta (o que sou eu?), a essa pergunta, pode-se depreender que Kant se afasta de captar uma essência, mas se inclina a procurar uma identidade singular. A questão do universal do homem em Kant, então, é redirecionada ao singular e particular, num nominalismo antropológico (SARDINHA, 2008, p. 59-61).

A proposta kantiana não deixou marcas superficiais na história humana, mas grande ruptura. Quando Aristóteles buscou captar a essência do homem, viu o homem tanto como animal que utiliza a linguagem (ARISTÓTELES, 2006, p. 193) e como animal político (ARISTÓTELES, 2001, p. 122); Kant, por sua vez, viu o homem como objeto do saber e sujeito que dá ao saber suas condições de possibilidade, i.e., empobrece o homem num empírico-transcendental, de tal forma que a morte do "homem" possibilitou uma antropologia moderna, do homem como produto de seu tempo (SARDINHA, 2008, p. 58).

\section{O NOMINALISMO E O DIREITO}

Servindo-se do desfecho do capítulo anterior, Kant, na fundamentação da metafísica dos costumes, busca conciliar a aplicação do princípio moral, o imperativo categórico, com os novos panoramas que estavam sendo desenhados pela modernidade. Pressupondo uma base contratualista de sociedade, um direito natural derivado da razão e a convivência entre arbítrios no Estado, necessário, pois, leis éticas e jurídicas com fundamentos racionais e de regramento moral (BARBOSA, 2010, p. 54), “O direito, portanto, é o conjunto das condições sob as quais o arbítrio de um pode conciliar-se com o arbítrio de outro segundo uma lei universal da liberdade". Aqui, a liberdade de um termina quando começa a do próximo. A obediência ao direito e de agir conforme este se torna uma medida ética para evitar a transgressão da liberdade alheia, àquele que transgride o direito cria um obstáculo à liberdade 
conforme as leis universais, caso em que o direito está vinculado a "uma competência para coagir quem o viola". (KANT, 2013, p. 230-231)

Ocorre que o manuseio dos instrumentos coercitivos está no direito positivo, de tal forma que o direito natural necessita realizar-se no direito positivo para se valer daqueles. $\mathrm{Na}$ verdade, o direito positivo como lei externa, deve ter sua fundamentação no direito natural, este mesmo que erige a autoridade do legislador. Nessa toada, a diferença entre direito e moral passa ao aspecto formal, de forma que aceitar a lei jurídica é estar na legalidade, motivo diferente do dever kantiano; já a legislação ética fica no aspecto moral, obediência por puro dever (BARBOSA, 2010, p. 57-59).

Desde de Ockham o jus passa a ser sinônimo de lei, no sentido que o direito expressa uma vontade, e a legislação transforma em produto da emanação do poder individual. Deixa o direito de observar objetivamente a ordem das coisas para analisar o subjetivo, individualista, focado na natureza do homem, suas faculdades e poderes (MARQUES, 2015, p. 820).

Este contexto é ilustrado no "o que é o iluminismo", no qual por um lado, o iluminismo seria maioridade do homem, culpado, pois, de sua própria incapacidade de entendimento sem a orientação de outrem. Por outro lado, apesar de serem permitidas observações posteriores, quando houver o interesse da comunidade, deve haver um mecanismo que torne alguns membros da comunidade de modo puramente passivo, para seguirem orientação do governo "para fins públicos ou de, pelo menos, serem impedidos de destruir tais fins. Neste caso, não é decerto permitido raciocinar, mas tem de se obedecer" (KANT, 2011).

Apesar de uma exposição extensa de Kant, este é imprescindível para compreendermos os paradigmas da ruptura com um modelo de sociedade anterior. A racionalidade universal e suas ideias vão fomentar um direito natural baseado na racionalidade, e ao lado de outros acontecimentos como o Romance Julia ou a nova Heloísa, em 1761 de Rousseau (HUNT, 2009, p. 35 e ss), vão estofar argumentos “autoevidentes" na declaração de direitos da Virgínia, que por sua vez, vai influenciar a revolução francesa e as futuras constituições ocidentais (GRAU, 2011, p. 45-46).

Com a revolução francesa tem-se o segundo marco na cultura jurídica ocidental, a primeira foi com Irnerius ao redescobrir o corpus iuris civiles de Justiniano (BOBBIO, 1995, p. 63-73; HESPANHA, 2012, p. 188). A revolução levou ao Código de Napoleão que veio a espalhar o Código Francês inicialmente por movimentos militares. Portalis que teve papel decisivo na elaboração do Código Francês, contestou Kant, denunciou os abusos do 
iluminismo, a destruição da tradição, ao ateísmo e materialismo que trará algum apoio ao movimento de restauração na Europa pós-napoleônica, com intenção de evitar uma tabula rasa de todo passado, mas de um ponto de início e chegada (BOBBIO, 1995, p. 63-73; PORTALIS, 2014).

O positivismo emerge da tentativa de transformar o direito em ciência (como a física, matemática, naturais e sociais). Ocorre que a fundação das ciências paradigmas era a sua avaloratividade (manter o juízo de fato e excluir o juízo de valor). A ruptura do mundo moderno requestou um novo perfil de cientista, este renuncia se colocar perante a realidade e ter uma atitude moralista ou metafísica, não há mais lógica (finalista) da natureza (como préordenada a um fim por Deus). O direito é estudado a partir do que é, não de como deveria ser, o direito como fato, não como valor. $\mathrm{O}$ direito deve ser definido à exclusão de valores como bem ou mal; justo ou injusto, real ou ideal. Observe-se que a tentativa kantiana da norma positiva estar de acordo com a natural foi enterrada, pois não há juízo de valor (BOBBIO, 1995, p. 135-137).

O critério do direito é a validade, se está de acordo com uma produção "científica", seu antônimo a invalidade, se existe ou não; já o valor que não mais faz parte do direito tem seu antônimo no desvalor, ou, injustiça. Esta concepção vai ao encontro do nominalista Hobbes, para quem, no estado de natureza não há como distinguir o justo e o injusto, este critério só surgiria com o comando do soberano de um Estado constituído, a ordem é justa e a vedado injusto (BOBBIO, 1995, p. 137).

Um direito desvinculado com a ética, finalidade e conteúdo; que apenas preza pelo rigor formal vai permitir tornar o direito uma técnica social para influir na conduta humana (BOBBIO, 1995, p. 145), atributo que é diluído no direito, cria a ilusão de desaparecer a dominação transmutada em obrigação e obediência (ZENNI, 2005, p. 16), Infelizmente, o positivismo permitiu que grandes atrocidades fossem legitimadas pela norma formal. Após a Segunda Guerra Mundial, foi necessário rever a imagem de pessoa e seu valor que fundava a ideia de personalismo (PERLINGIERI, 2002, p. 35-36). As potencialidades animalescas do homem na $2^{\mathrm{a}}$ Guerra Mundial assolaram a Europa e formaram laços transnacionais pela preservação da humanidade e de seus valores (SCHREIBER, 2011, p. 6). O pós-guerra banhou os sistemas jurídicos atribuindo à dignidade ao homem, ainda que inicialmente apenas de ordem formal (FACHIN, 1992/1993).

É neste contexto que teóricos como Ronald Dworkin (1931-2013) emergem a fim de salvar o direito positivo por meio dos princípios jurídicos. Apesar de não ser o escopo aprofundar este assunto específico, delineia-se sucintamente expoentes atuais da filosofia do 
direito que buscam adequar o direito à uma nova realidade. Dworkin (1967, p. 14-16) criticou o sistema positivista ilustrado por Hart, a fonte do social do direito, a validade, seria uma questão de fato, na sua relação com as demais, a norma não é válida em si, mas aceita como um fato social; diferente de Hart que o direito é formado de regras que não dependem de juízos valorativos. Doravante, atacou a dificuldade dos juristas em conceituarem direito jurídico e obrigação jurídica, conceitos que interferem diretamente na vida das pessoas e autoriza o Estado a punir ou coagir, os nominalistas resolveriam ignorando-o, já que sã insolúveis é porque são irreais (DWORKIN, 2002, p. 23-27). O soberano, eventualmente, vai emitir comandos vagos ou pouco claros, de forma que aos juízes caberá criar uma nova regra ou adaptar as antigas (DWORKIN, 2002, p. 29), o que demonstra um caráter de argumentação entre os juristas.

Ao contrário das normas-regras positivas que seguem o modelo "tudo ou nada", Dworkin enfatizou o papel dos princípios, negligenciados pelo modelo positivista, que evidenciariam a natureza moral da argumentação jurídica, aplicadas por ponderação e/ou balanceamento feitos por justificação argumentativa. Assim, os princípios seriam a intenção moral do direito (ENCICLOPÉDIA, 2017, p. 6). O direito seria, assim, integrado tanto por regras como princípios, não é mera ciência, mas é um conceito interpretativo, de forma que a argumentação jurídica interprete moralmente a via da prática social (RODRIGUES, 2013, p. 306).

O direito nominalista inspirado em ideias como a de Kelsen (1998) que definiria o direito como uma série concatenada e hierarquizada de normas que teriam sua legitimidade atribuída à norma imediatamente superior, até a norma hipotética fundamental; Assim, um direito neutro e racional que em última análise de fundamenta numa ideia, uma ideia de obediência dogmática. Hart (2007), por seu turno, que a partir da ideia de Kelsen, veio legitimar o direito por meio de normas coercitivas acompanhadas de sanção, e normas de legitimidade às normas coercitivas. Estas concepções nominalistas do direito perdem cada vez mais espaço para correntes neopositivistas que buscam o direito além de uma intenção positiva de simples cumprimento da norma pura, mas da sua reaproximação com valores e dignidade, esta que se torna o centro axiológico do direito atual e do objetivo declarado dos Estados no pós-guerra, evento marcado pela instrumentalização e legitimação do direito nominalista, um direito sem responsabilidade pelo conteúdo material da norma, instrumentalizados e legitimados pelo direito nominalista.

\section{REFLEXOS NA PERSONALIDADE}


A personalidade não se restringe aos atributos dela que são tutelados juridicamente por meio dos direitos de personalidade, estes, se pensados resguardariam uma personalidade nominalista que não transcenderia tais atributos, o que não é verdade, tanto que juridicamente temos um clausula geral de proteção. Mas a personalidade além de ser a soma dos atributos elencados pela legislação, é uma unidade, um universal que remete ao termo pessoa e ser humano, entender o que é pessoa e ser humano, é entender o que significa personalidade, é o primeiro passo para intelectualmente perseguirmos sua essência, o universal.

"O homem é um animal metafísico", esta constatação não descarta que somos biológicos e temos contato com o mundo sensível pelos sentidos. E a linguagem não alcança toda a realidade, o espírito sente o fisicamente ausente. A vida humana ao ser puramente biológico e racional é tudo, mas o ser é capaz de se sacrificar por uma causa, a vida também é propósito (SUPIOT, 2007, p. 7).

O homem que busca ser livre como sujeito de direito deve estar vinculado por palavras que o prendam a outros homens. Direito e palavra tem seus vínculos entrelaçados e se confundem, este direito que vincula o infinito de nossa mente à finitude de nossa experiência sensível, é o carrasco antropológico de instituição da razão (SUPIOT, 2007, p. 810). Não somos nem puro animal nem puro espírito, mas animal metafísico.

Nesse mesmo sentido, da natureza humana, o homem é, simultaneamente, ser e deverser. O grupo se mostra imprescindível para o aperfeiçoamento pessoal, somos convocados naturalmente por um feixe natural de reivindicações axiológicas (ZENNI, 2004, p. 8).

Esse empobrecimento teleontológico da personalidade, próprio do nominalismo, vem ao encontro do cálculo, do capitalismo e da ciência moderna. $\mathrm{O}$ capitalismo não busca a riqueza material, mas o domínio da quantidade que subjuga as diferenças, as qualidades. $\mathrm{O}$ cálculo, por sua vez, é atributo da razão, não sua totalidade, esta concepção cria uma ideologia econômica que o ser racional, o homem nominalista, é um puro ser de cálculo, e que seu comportamento pode ser calculado e programado como um computador (SUPIOT, 2007, p. 11-13). E a personalidade é gravemente afetada neste contexto, pois o cálculo nominalista vai tratar como irreal e desconsiderar tudo que não puder ser traduzido em números.

A sociedade moderna traz novas identidades e fragmenta o indivíduo, antes visto como uno. Desde o final do século XX, os nossos parâmetros como indivíduos sociais vem se fragmentando, inflige a percepção de identidade como sujeitos integrados. Stuart Hall (2006, p. 7-9) apresenta três concepções de identidade: a do sujeito do iluminismo, sociológico e pós-moderno. 
O sujeito do iluminismo era concebido uno, centrado, dotado de razão, consciência e ação, a identidade existiria com o nascimento, um núcleo, denota-se uma individualidade exacerbada e masculina. O sociológico tinha esse mesmo núcleo com contornos novos, voltado para suas relações, uma identidade interativa, a identidade deixa de ser imutável e solipsta. O sujeito pós-moderno é uma consequência do anterior, cada vez mais provisório, variável e efêmero, temos várias identidades fragmentadas que até podem ser contraditórias ou não resolvidas; a identidade passa a ser definida historicamente (HALL, 2006, p. 10-13).

A deterioração da ética tradicional fundada nos valores judaico-cristãos derrubou diversas barreiras morais ao modelo utilitarista, burguês e capitalista de vida, permitiu-se que a transcendência conceda lugar à racionalidade; no lugar do manual, o técnico; a virtude cede ao lucro; e a integração se fragmenta (BITTAR, 2012, p. 78-79).

No contexto que o mercado já encobriu a ética, o direito e a personalidade, nossa identidade é comprada por meio de escolhas, um estilo de vida, o padrão de consumo, "'nossa individualidade' e nossa identidade são moldadas dentro de escolhas e estruturas coletivas mais amplas". A cultura do consumo explora essa nossa natureza bidimensional, nos cegando de uma dimensão, e essa incompletude é atacada com propagandas, experiências e panaceias que nos prometem uma identidade (FILHO, 2003, p. 73-75).

O direito funcional, notadamente sistêmico, desnuda o humano e o conduz aos resultados apriorísticos da linguagem algorítmica. Pessoas são conceitos vazios ou ideias de um progresso histórico que se mostra frustrado. Personalidade é a válvula que se vale a razão estratégica para garantir o fluxo das trocas no mundo das mercadorias.

\section{CONCLUSÃO}

Sem a pretensão de esgotar o tema, ainda que tenha sido recortado um grande lapso de tempo, parece que a pesquisa colheu frutos. A hipótese inicial foi indeferida, não foi Guilherme de Ockham que criaria o nominalismo, estritamente, foi o que provou à sua época. Não foi a doutrina dos direitos subjetivos, também, que trariam o individualismo para a modernidade, ainda que tenha influenciado, não teve a pujança para ser tão decisivo nesse sentido.

Foi descoberto que o tema do nominalismo tem uma ruptura em Guilherme de Ockham, mas que envolve a querela dos universais e esta tanto remonta à antiguidade quanto protrai para a modernidade. Foi percebido que o tema é extremamente extenso na nossa história e ainda não foi finalizado. 
Esse embate dos universais trouxe o nominalismo como vitorioso na reestruturação da idade moderna, na construção de novos pilares, e o direito foi influenciado diretamente, teve que se moldar de acordo com a ciência e a racionalidade que encabeçavam o movimento.

O direito que sempre teve ligação muito estreita com a ética, com valores transcendentais foi preenchido por dogmas funcionais e passível de manuseio como instrumento social de controle de comportamento.

Tanto a querela dos universais quanto a imposição do direito como ciência vieram reverberar na personalidade. A personalidade que era antes vista de forma dual, tanto espírito quanto matéria, é empobrecida ontoteleogicamente, perde causa inicial e final; perde suas referencias para construção da identidade e acaba por vagar na materialidade no esmero de construir sua identidade fragmentada a partir de um padrão de consumo.

A relevância da pesquisa se mostra muito atual às discussões sobre a personalidade, direito e até à ciência. Muitas correntes vêm criticando os contornos nominalistas da nossa sociedade, e o tema pesquisado tem muito a enriquecer com o debate, merecendo investigações mais profundas sobre pontos específicos.

\section{QUERELA OF UNIVERSALS, LAW AND PERSONALITY}

Abstract: The initial objective was to investigate nominalism and the surrounding context. The methodology used was hypothetico-deductive, with research on articles, dissertations, theses and books. The results indicate that the debate of universals has not yet ended and this reverberates in law and personality.

Keywords: Querela of universals. Middle Age. Realism and nominalism. Right and personality.

\section{REFERÊNCIAS}

AARON, R.I. The theory of universals, Oxford, Clarendon Press, 1952,

Araujo, Cícero, Araujo. Teologia política e secularização. Revista brasileira de ciências sociais, São Paulo, v.28, n.83, outubro, 2013, p. 217-224. Disponível em: $<$ http://www.scielo.br/scielo.php?script=sci_arttext\&pid=S0102-

$69092013000300014 \& \operatorname{lng}=$ en\&nrm=iso>. Acesso em 07 de out. 2018.

ARISTÓTELES. História dos animais, trad. Maria de Fátima Sousa e Silva. Lisboa: Imprensa Nacional-Casa da moeda, 2006.

ARISTÓTELES. Organon, trad. Pinharanda Gomes. $1^{\text {a }}$ Ed. Lisboa: Guimarães editores lda. 1985. 
ARISTÓTELES. Política, trad. Pedro Constantin Tolens. 5a Ed. São Paulo: Martin Claret Ltda, 2001.

AUSGUSTO, Luís m. Eckhart the "unconscious". Revista filosófica de Coimbra, v.17, n.33, marco, 2008, p. 155-168. Disponível em: < https://www.uc.pt/fluc/dfci/public_/publicacoes/eckhart_the_unconscious $>$. Acesso em: 07 de out. 2018.

AZEVEDO, Leandro Vilela de. As obras de John wycliffe inseridas no contexto religioso de sua época: da suma teológica de Aquino ao concílio de Constança, dos espirituais fransciscanos a Guilherme de ockham. 2010. 493 f. Tese (doutorado em história social) universidade de São Paulo, São Paulo, SP.

BARBOSA, Evandro. O problema da legitimidade do direito em Kant e Habermas. Revista Kinesis, Marília, SP, v.2, n.4, dezembro, 2010, p, 53-82. Disponível em: < http://www2.marilia.unesp.br/revistas/index.php/kinesis/article/view/4366>. Acesso em: 12 de out. 2018.

BENÍTEZ, Francisco Carpintero. Los escolásticos espanõles em los inícios del liberalismo político y jurídico. Revista de estúdios históricos-jurídicos, Valparaíso, Chile, n.25, v,1, 2003, p. 341-373. Disponível em: $<$ https://scielo.conicyt.cl/scielo.php?script=sci_arttext\&pid=S0716$54552003002500009 \& \operatorname{lng}=\mathrm{es} \& n r m=\mathrm{iso} \& \operatorname{lng}=\mathrm{es}>$. Acesso em: 06 de out. 2018.

BERTELLONI, Francisco. El resultado del conocimiento universal em el segundo comentário de Boécio a La isagogé de Porfírio. Revista Scripta Mediaevalia, Mendonza, Argentina, v. 5, n. 1, 2012, p. 11- 34. Disponível em: http://revistas.uncu.edu.ar/ojs/index.php/scripta/article/view/480>. Acesso em: 15 de out. 2018.

BITTAR, Eduardo C.B. Curso de ética jurídica: ética geral e profissional. 9 Ed. São Paulo: Saraiva, 2012.

BOBBIO, Noberto. O positivismo jurídico: lições de filosofia do direito, trad. Nello Morra. São Paulo: Ícone, 1995.

BORGES, Thiago José. A tradição dos loca sancta: sacralização e representação dos espaços sagrados no ocidente medieval cristão (século VIII-XV). 2017. 274 f. Tese (Doutorado em história) - Universidade de Brasília, Brasília.

BRANCO, Pedro Villas Bôas Castelo. Secularização inacabada: política e direito em Carl Schmitt. Curitiba, Appris, 2011.

CAMPELO, Olívia Brandão Melo. A ideia de justiça na crise moral contemporânea. 2016. 119 f. Tese (Doutorado em direito) - PUCSP, São Paulo, SP.

CARVALHO, Mário Santiago de. Sobre as origens dos paradigmas modernos do universalismo e do individualismo (a propósito de "cidadania" e "cultura"). Revista filosófica de Coimbra, Coimbra, Portugal, v.14, n.27, março, 2005, p. 43-79. Disponível em: $<$ 
https://www.uc.pt/fluc/dfci/public_/publicacoes/sobre_as_origens_dos_paradigmas_modern os>. Acesso em: 07 de out. 2018.

COXITO, Amândio A. Luís A. Vernei e a filosofia europeia do seu tempo: o problema dos universais. Revista filosófica de Coimbra, v.3, n.6, out, 1994, p. 293-320. Disponível em: $<$ https://www.uc.pt/fluc/dfci/public_/publicacoes/luis_a_vernei $>$. Acesso em: 07 de out. 2018.

CRESSONI, André. Idealismo e metafísica platônica - uma releitura a partir de Hegel. Revista de Estudos Filosóficos e Históricos da Antiguidade, Campinas, n. 29, jan-dez, 2015, p. 37-87. Disponível em: https://www.ifch.unicamp.br/ojs/index.php/cpa/article/download/2227/1641. Acessado em: 01 de out. 2018.

CRUZ, Marcilio Bezerra; e SILVA, Claubervan Lincow. O nominalismo de roscelino de compiègne: os universais como "flatus vocis". Cadernos do PET Filosofia, Pernambuco (UFPB), v. 5, n.9, jan-jul, 2014, p. 48-55. Disponível em: < http://www.ojs.ufpi.br/index.php/pet/article/view/2962/0>. Acesso em: 15 de out. 2018.

DESCARTES, René. O discurso do método, trad. Paulo Neves. Santa Maria: Gráfica e Editora Pallotti. 2005.

DESCARTES, René. Princípios da filosofia, trad. João Gama. Lisboa: Edições 70, Lda. 2004.

DURANT, Will. A história da filosofia, trad. Luiz Carlos do Nascimento Silva. Rio de Janeiro: Editora Nova Cultura Ltda. 1996.

DWORKIN, Ronald. Levando os direitos a serio, trad. Nelson Boeira. São Paulo: Martins Fontes, 2002.

DWORKIN, Ronald M. The model of rule. The university os Chicago law review, v.35, n.1, 1967, p. 14-16. Disponível em: < http://users.umiacs.umd.edu/ horty/courses/readings/dworkin-1967-model-of-rules.pdf $>$. Acesso em: 13 de out. 2018.

Enciclopédia Jurídica da PUCSP, tomo I (recurso eletrônico): teoria geral e filosofia do direito. Celso Fernandes Campilongo (coord), Alvaro Gonzaga, André Luiz Freire - São Paulo: Pontifícia Universidade Católica de São Paulo, 2017. Disponível em: < https://enciclopediajuridica.pucsp.br/pdfs/ronald-dworkin---teorico-dodireito_58fc0dafe9466.pdf>. Acesso em: 13 de out. 2018.

FERREIRA, Anderson D'arc. Ockham e a filosofia da mente: aproximações ao externalismo na filosofia contemporânea. Revista Problemata - revista internacional de filosofia, v.2, n.1, 2011, p, 144-169. Disponível em: < http://www.periodicos.ufpb.br/ojs/index.php/problemata/article/view/10447>. Acesso em: 03 de out. 2018.

FILHO, João Freire. Mídia, consumo cultural e estilo de vida na pós-modernidade. Revista ECO-PÓS - UFRJ, Rio de Janeiro, v.6, n.1, janeiro-julho, 2003, p. 72-97. Disponível em: < 
https://revistas.ufrj.br/index.php/eco_pos/article/viewFile/1144/1085>. Acesso em: 13 de out. 2018.

GILSON, Etienne. A filosofia na idade média, trad. Eduardo Brandão. São Paulo: Martins Fontes, 1995.

GRAU, Luis. El constitucionalismo americano: materiales para um curso de historia de las constituciones. Madrid (universidad Carlos III): Dykisonm, 2011.

GUERRA FILHO, Willis Santiago. Sobre a origem medieval de noções modernas como a de direitos humanos, Revista Panóptica, Vitória, v.8, n.2 (n.26), p. 15-40, jul/dez. 2013. Disponível em: < http://www.panoptica.org/seer/index.php/op/article/view/308/329>. Acesso em: 05 de out. 2018.

GUERRA FILHO, Willis Santiago; e CANTARINI, Paola. Teoria poética do direito. Rio de janeiro: Lumen Juris, 2015.

HAMLIN, Cynthia Lins. Realismo crítico: um programa de pesquisa para as Ciências Sociais. Revista Dados - Instituto de Estudos Sociais e políticos (IESP) da unversidade do Estado do Rio de Janeiro, Rio de Janeiro, v. 43, n. 2, p. 00, 2000. Disponível em: $<$ http://www.scielo.br/scielo.php?script=sci_arttext\&pid=S0011-

$52582000000200006 \& \operatorname{lng}=\mathrm{en} \& n r m=\mathrm{iso}>$. Acesso em: 12 de out. 2018.

HALL, Stuart. A identidade cultural na pós-modernidade, trad. Tomaz Tadeu da Silva e Guacira Lopes Louro. 11 Ed. Rio e Janeiro: DP\&A editora, 2006.

HART, H.L.A. O conceito de direito, trad. A. Ribeiro Mendes. 5 Ed. Lisboa: Fundação calouste gulbenkian, 2007.

HERNÁNDEZ, José López. El concepto de legitimidad em perspectiva histórica. Revista cuadernos eletrónicos de filosofia Del derecho, - el institut de La universitat de valència, Espanha, n. 18, v. 1, 2009, p. 153-166. Disponível em:< https://ojs.uv.es/index.php/CEFD/article/view/116/124>. Acesso em: 06 de out. 2018.

HESPANHA, António Manuel. A cultura jurídica europeia: síntese de um milénio. Coimbra: Almedina, 2012

HOBBES, Thomas. Leviatã, ou, matéria, forma e poder de um Estado Eclesiástico e civil, trad. Rosina D’Angina. São Paulo: Martin Claret, 2009.

HUNT, Lynn. A invenção dos direitos humanos: uma história, trad. Rosaura Eichenberg.São Paulo: Companhia das letras, 2009.

IMAGUIRE, Guido. O avestruz Nihilista. Revista Notae Philosophicae Scientiae Formalis, Santa Maria, RS, v.2, n.1, p.33-44, maio, 2013. Disponível em: $<$ http://gcfcf.com.br/pt/files/2013/07/Imaguire-Guido-NPSF-vol.-2-n.-1.pdf $>$. Acesso em: 12 de out. 2018.

IMAGUIRE, Guido. Ockham's razor and chateaubriand's goatee. Revista Manuscrito Rev. Int. Fil., Campinas, v. 31, n. 1, p. 139-154, jan.-jun. 2008. Disponível em: < 
https://periodicos.sbu.unicamp.br/ojs/index.php/manuscrito/article/viewFile/8642095/9586> . Acesso em: 12 de out. 2018.

JUNIOR, Pedro Leite. O nominalismo de Ockham: ontologia e semântica. Revista Thaumazein, v.4, n.8, 2011, p.29-45. Disponível em: < https://www.periodicos.unifra.br/index.php/thaumazein/article/view/76>. Acesso em: 03 de out. 2018.

JUNIOR, Pedro Leite. O nominalismo psicológico acerca dos universais em João Buridano. Revista Ágora, Espírito Santo, v.1, n.2, 2011, p. 225-242. Disponível em: $<$ http://www.unicap.br/ojs/index.php/agora/article/viewFile/159/145>. Acesso em: 03 de out. 2018.

KANT, Immanuel. Fundamentação da metafísica dos costumes, trad. Paulo Quintela. Lisboa: Edições 70 lda, 2007.

KANT, Immanuel. Metafísica dos costumes, trad (primeira parte). Clélia Aparecida Martins. Petrópolis, RJ: Editora Vozes, 2013.

KANT, Immanuel. O que é iluminismo, trad. Artur Morão. Covilhã: Lusofia press, 2011. Disponível em: < http://www.lusosofia.net/textos/kant_o_iluminismo_1784.pdf $>$. Acesso em: 13 de out. 2018.

KELSEN, Hans. Teoria pura do direito, trad. João Baptista Machado. 6 Ed. São Paulo: Martins Fontes, 1998.

KNEALLE, William; KNEALLE, Martha. O desenvolvimento da lógica. $3^{\text {a }}$ Ed. Lisboa: Fundação Calouste Gulbeankian, 1991.

MADUREIRA, Jonas Moreira. O intelecto e a imaginação no conhecimento de deus segundo Tomás de Aquino. Aristotelismo e neoplatonismo. 2014. 134 f. Tese (Doutorado em filosofia) - universidade de São Paulo, São Paulo, SP.

MARQUES, Gabriel Lima. A liberdade como direito subjetivo no pensamento de Guilherme de Ockham. Revista quaestio iuris, Rio de Janeiro, v.8, n.2, 2015, p. 807-825. Disponível em: <http://www.e-publicacoes.uerj.br/index.php/quaestioiuris/article/view/16900/12727>. Acesso em: 14 de out. 2018.

NASSARO, Silvio Lúcio Franco. A unidade da verdade em Erasmo. 2005. 183 f. Dissertação (Mestrado em filosofia) - universidade de São Paulo, SP.

PERLINGIERI, Pietro. Perfis do direito civil: introdução ao direito civil constitucional, Trad. Maria Cristina de Cicco. 3 Ed. Rio de Janeiro: Renovar, 2002.

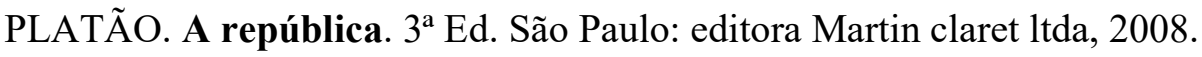

PORFÍRIO. Isagoge. Lisboa: Guimarães, 1994.

PORTALIS, Jean-Étienne-Marie, trad. Adela Mora. Discurso preliminar sobre el proyecto de Código civil. Madrid, 2014. Disponível em: <https://earchivo.uc3m.es/handle/10016/19797>. Acesso em: 13 de out. 2018. 
RASCH, Elton Luiz. A silogística categórica dos analíticos anteriores de Aristóteles. 2013. 99 f. Dissertação (Mestrado em Filosofia) - Universidade Federal de Santa Maria, Santa Maria, RS.

RODRIGUES, Fernando. Crítica ao positivismo e interpretação. Revista direito e praxis, Rio de Janeiro, v.4, n.7, 2013, p. 305-318. Disponível em: <http://www.epublicacoes.uerj.br/index.php/revistaceaju/article/view/8351>. Acesso em: 13 de out. 2018.

RUSSELL, Bertrand. História da filosofia ocidental. São Paulo: Companhia editora nacional, 1969. Livro II.

SANDOVAL, Rafael Antônio dos Santos. Termos e universal em Guilherme de ockham: a lógica como ciência do discurso. 2016. Dissertação (mestrado em filosofia) - universidade de Brasília, Brasília.

SANTOS, José Francisco dos. Conhecimento e instinto em Pierce e Dewey: uma epistemologia realista e "naturalizada". Revista Cognitio-estudos: revista eletrônica de filosofia, São Paulo, v.4, n.1, jan-jun, 2007, p. 60-70. Disponível em: < https://www.pucsp.br/pragmatismo/dowloads/6cog_est_v4n1_santos_jose_f.pdf $>$. Acesso em: 12 de out. 2018.

SANTOS, Bento Silva. Os argumentos de Boécio (CA. 480-524) e contra os universais no "segundo comentáro à isagoge de porfírio". Revista Síntese, Belo Horizonte, v. 30, n. 97, p. 187-202, 2003. Disponível em: < http://www.faje.edu.br/periodicos/index.php/Sintese/article/view/496>. Acesso em: $13 \mathrm{de}$ out. 2018.

SCHMITT, Carol. Teologia política, trad. Francisco Javier Conde e Jorge Navarro Pérez. Madrid: Editora Trotta, 2009.

SCHREIBER, Anderson. Direitos da personalidade. São Paulo: Atlas, 2011.

SILVEIRA, Fernando Lang da. A teoria do conhecimento em Kant: o idealismo transcendental. Revista Caderno brasileira de ensino de física - Universidade Federal de Santa Catarina, Santa Catarina, v.19, n.especial, março, 2002, p. 28-51. Disponível em: < https://periodicos.ufsc.br/index.php/fisica/article/view/10053>. Acesso em: 12 de out. 2018.

SOUZA, LAIZA RODRIGUES. O problema dos universais medievos: o nominalismo de ockham e a passagem da ontologia à lógica. 2015. 131 f. Dissertação (Mestrado em Filosofia) - Universidade Federal da Paraíba, João Pessoa, PB.

SUPIOT, Alain. Homo juridicus: ensaio sobre a função antropológica do direito, trad. Maria Ermantina de Almeida Prado Galvão. 1 Ed. São Paulo: WMF Martins Fontes, 2007.

TÔRRES, Moisés Romanazzi. A herança na primeira escolástica de filosofia da alta idade média: Boécio enquanto autoridade na questão dos universais. Revista Brathair - Revista de estudos celtas e germânicos, Maranhão, edição especial I, 2007, p, 27-97. Disponível em: < http://ppg.revistas.uema.br/index.php/brathair/article/viewFile/543/468>. Acesso em: 03 de out. 2018. 
VASCONCELLOS, Manoel. A crítica de Anselmo a roselino na epistola de incarnatione verbi. Revistas Dissertatio, Pelotas, v.1, n.17-18, 2003.

VILELA, Orlando. O drama Heloísa-Abelardo. Belo Horizonte: Itatiana, 1986.

ZENNI, Alessandro Severino Vallér. Direito e poder na filosofia pós-moderna. Revista jurídica cesumar, v.5, n.1, p. 13-30. Disponível em: < http://periodicos.unicesumar.edu.br/index.php/revjuridica/article/view/334>. Acesso em: 13 de out. 2018.

ZENNI, Alessandro Severino Vallér. Pessoa e justiça: questão de direito. Porto Alegre: Sergio Antonio Fabris. 2018.

ZENNI, Alessandro Severino Vallér. O retorno à metafísica como condição para concretização da dignidade da pessoa humana. Revista Jurídica Cesumar, Maringá, v.4, n.1, 2004, p. 5-14. Disponível em: http://periodicos.unicesumar.edu.br/index.php/revjuridica/article/view/359/423>. Acesso em: 13 de out. 2018.

Trabalho de enviado em 24 de janeiro de 2019 Aceito em 06 de fevereiro de 2020 